This article was downloaded by: [National Taiwan University]

On: 6 November 2008

Access details: Access Details: [subscription number 731692385]

Publisher Taylor \& Francis

Informa Ltd Registered in England and Wales Registered Number: 1072954 Registered office: Mortimer House, 37-41 Mortimer Street, London W1T 3JH, UK

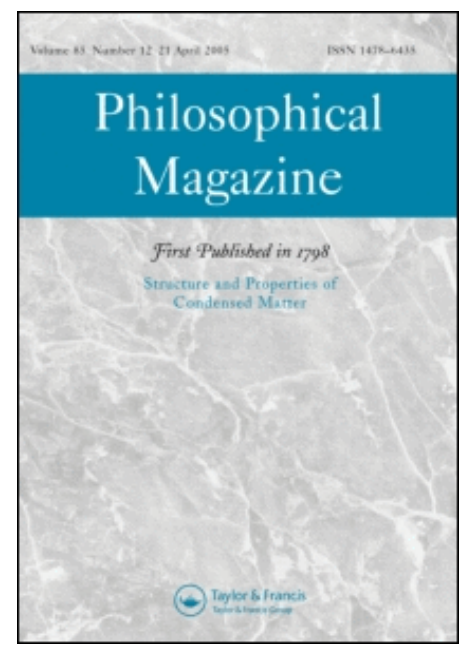

\title{
Philosophical Magazine
}

Publication details, including instructions for authors and subscription information: http://www.informaworld.com/smpp/title content=t713695589

\section{Interfacial reactions of rf-sputtered TiNi thin films on (100) silicon with a SiN diffusion barrier}

S. K. Wu a; J. J. Su a; J. Y. Wang ${ }^{b}$

a Department of Materials Science and Engineering, National Taiwan University, Taipei 106, Taiwan ${ }^{\mathrm{b}}$ Materials and Optical-Electronics Division, Chung-Shang Institute of Science and Technology, Lung-Tan,

Tao-Yuan 325, Taiwan

Online Publication Date: 21 April 2004

To cite this Article Wu, S. K., Su, J. J. and Wang, J. Y.(2004)'Interfacial reactions of rf-sputtered TiNi thin films on (100) silicon with a SiN diffusion barrier',Philosophical Magazine,84:12,1209 - 1218

To link to this Article: DOI: $10.1080 / 14786430310001646745$

URL: http://dx.doi.org/10.1080/14786430310001646745

\section{PLEASE SCROLL DOWN FOR ARTICLE}

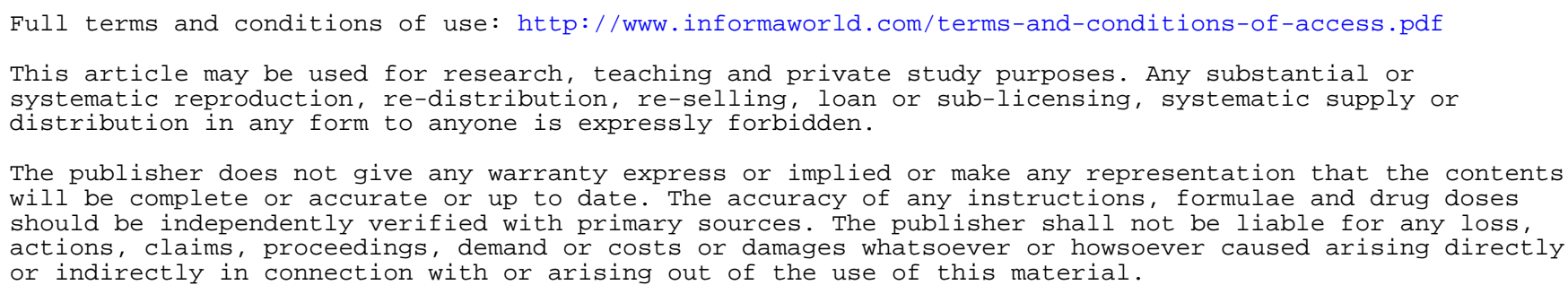




\title{
Interfacial reactions of $\mathrm{rf}$-sputtered $\mathrm{TiNi}$ thin films on (100) silicon with a SiN diffusion barrier
}

\author{
S. K. Wu†, J. J. Su \\ Department of Materials Science and Engineering, National Taiwan University, \\ Taipei 106, Taiwan \\ and J. Y. WANG \\ Materials and Optical-Electronics Division, Chung-Shang Institute of Science \\ and Technology, Lung-Tan, Tao-Yuan 325, Taiwan
}

[Received 11 August 2003 and accepted in revised form 28 October 2003]

\begin{abstract}
Silicon nitride $(\mathrm{SiN})$ with a $50 \mathrm{~nm}$ thickness on $\mathrm{Si}(100)$ as a thermal barrier was obtained by plasma-enhanced chemical vapour deposition (PECVD). TiNi thin films were rf sputtered on a $\mathrm{SiN} / \mathrm{Si}$ substrate and then annealed at $400-700^{\circ} \mathrm{C}$ for $30 \mathrm{~min}$. Their interfacial reactions were studied using transmission electron microscopy, X-ray diffraction and Auger electron spectroscopy analyses. Experimental results show that the thickness of reaction layer in $\mathrm{TiNi} / \mathrm{SiN} / \mathrm{Si}$ specimens is clearly reduced, compared with that in $\mathrm{TiNi} / \mathrm{Si}$ specimens under the same annealing conditions. The significant effect of the SiN layer as a diffusion barrier in $\mathrm{TiNi} / \mathrm{SiN} / \mathrm{Si}$ can be recognized. $\mathrm{N}$ and $\mathrm{Si}$ atoms diffuse from the $\mathrm{SiN}$ layer to react with TiNi films at $500^{\circ} \mathrm{C}$ and $600^{\circ} \mathrm{C}$ respectively. The $\mathrm{TiN}_{1-x}$ phase is formed in specimens annealed at $500^{\circ} \mathrm{C}$, and mixed $\mathrm{Ti}_{2} \mathrm{Ni}_{3} \mathrm{Si}$ and $\mathrm{Ti}_{4} \mathrm{Ni}_{2} \mathrm{O}$ compounds are found at $600^{\circ} \mathrm{C}$. In the specimen annealed at $700^{\circ} \mathrm{C}$, the reaction layer has sublayers in the sequence $\mathrm{TiNi} / \mathrm{Ti}_{4} \mathrm{Ni}_{2} \mathrm{O} / \mathrm{Ti}_{2} \mathrm{Ni}_{3} \mathrm{Si} / \mathrm{TiN}_{1-x} /$ $\mathrm{SiN} / \mathrm{Si}$. The SiN thermal barrier obtained by PECVD caused quite different diffusion species to cross the interfaces between $\mathrm{TiNi} / \mathrm{SiN} / \mathrm{Si}$ and $\mathrm{TiNi} / \mathrm{Si}$ specimens during the annealing.
\end{abstract}

\section{$\S 1$. INTRODUCTION}

TiNi shape memory thin films are materials with a high potential for fabricating the microactuators and micropumps used in microelectromechanical systems because of the advantages of their large shape recovery force and strain. Hence, efforts have been made with TiNi thin films using rf sputtering techniques (Wolf and Heuer 1995, Bendahan et al. 1996, Stemmer et al. 1997, Miyazaki and Ishida 1999, Chen and Wu 1999, Matsunaga et al. 2000, Wu et al. 2001). Because the TiNi thin films are amorphous when initially deposited on to low-temperature substrates, thermal annealing is necessary for the crystallization of these films (Stemmer et al. 1997, Chen and Wu 1999, Wu et al. 2001). However, the film-substrate interface will interact during thermal annealing. These interfacial products will influence the

\footnotetext{
$\dagger$ Author for correspondence. Email: skw@ccms.ntu.edu.tw.
} 
film-substrate adhesion and other interfacial properties, thus affecting the performance of TiNi thin films as microactuators and micropumps (Wolf and Heuer 1995).

In our previous study, interfacial microstructures of TiNi thin films rf sputtered on to $\mathrm{Si}(100)$ and post-annealed at $400-700^{\circ} \mathrm{C}$ for $30 \mathrm{~min}$ were investigated (Wu et al. 2001). For annealing temperatures below $600^{\circ} \mathrm{C}$, Ni atoms are the primary diffusion species and $\mathrm{NiSi}_{2}$ compound forms towards the Si substrate at $400^{\circ} \mathrm{C}$. TiNi thin films initially crystallize at $500^{\circ} \mathrm{C}$. Si and $\mathrm{Ti}$ atoms begin to migrate in specimens annealed at $600^{\circ} \mathrm{C}$. At this temperature, a near- $\mathrm{Ti}_{4} \mathrm{Ni}_{4} \mathrm{Si}_{7}$ compound on the $\mathrm{NiSi}_{2}$ side and a near-TiNiSi compound on the TiNi film side are simultaneously produced at the interface. For specimens annealed at $700^{\circ} \mathrm{C}$ for $30 \mathrm{~min}, \mathrm{Ti}_{4} \mathrm{Ni}_{4} \mathrm{Si}_{7}$ forms a layer with a thickness greater than $0.3 \mu \mathrm{m}$, while TiNiSi forms a layer with a thickness greater than $0.5 \mu \mathrm{m}$. Clearly, the amorphous rf-sputtered TiNi films crystallize at $500^{\circ} \mathrm{C}$, but $\mathrm{Ni}$ atoms in TiNi films have diffused into the Si substrate at $400^{\circ} \mathrm{C}$. In other words, the interfacial $\mathrm{NiSi}_{2}$ compound forms at the TiNi-Si interface during the TiNi films crystallization if there is no diffusion barrier existing in between the TiNi thin film and the Si substrate.

Silicon nitride obtained by plasma-enhanced chemical vapour deposition (PECVD) is widely used in the microelectronics industry as a diffusion barrier coating (Smith 1995). The silicon nitride obtained by PECVD (abbreviated here as SiN) is highly non-stoichiometric and has bonded H (Mar and Samuelson 1980, Chang et al. 1988). In this study, a layer of $\mathrm{SiN}$ was deposited on to $\mathrm{Si}(100)$; then TiNi thin films were rf sputtered on to it; finally they were annealed at temperatures between 400 and $700^{\circ} \mathrm{C}$ for $30 \mathrm{~min}$. The reaction phases and microstructures at the TiNi-SiN-Si interfaces resulting from the post-deposition thermal annealing are investigated. The difference between the interfacial reactions at the TiNi-Si and $\mathrm{TiNi}-\mathrm{SiN}-\mathrm{Si}$ interfaces are also discussed.

\section{§2. EXPERIMENTAL PROCEDURE}

A SiN layer $50 \mathrm{~nm}$ thick was deposited by PECVD on to the (100) surface of cleaned and oxide-etched Si wafers of 3 in diameter at the National Nano-Device Laboratory, National Science Council, Hsinchu, Taiwan, using an STS multiplex cluster system with frequency $380 \mathrm{kHz}$. In this system, silane $\left(\mathrm{SiH}_{4}\right)$ and $\mathrm{NH}_{3}$ were used as reaction gases, and $\mathrm{N}_{2}$ as the carrying gas. Then near-equiatomic TiNi thin films were sputtered on to $\mathrm{SiN} / \mathrm{Si}$ at room temperature using a magnetron gun in a high-vacuum $\left(1 \times 10^{-7}\right.$ Torr $)$ base pressure chamber. The sputtering conditions were as follows: sputtering pressure, $10 \mathrm{mTorr}$, target-substrate distance, $50 \mathrm{~mm}$; dc power, $200 \mathrm{~W}$; deposition rate, about $5 \AA \mathrm{sec}^{-1}$. The targets used in this study were a $\mathrm{Ti}_{49} \mathrm{Ni}_{51}$ disc of 2 in diameter. The sputter-deposited TiNi specimens with thicknesses of 0.4 and $1.5 \mu \mathrm{m}$ were scaled in evacuated quartz tubes, thermally annealed at 400 , 500,600 and $700^{\circ} \mathrm{C}$ for $30 \mathrm{~min}$ and then furnace cooled to room temperature.

The annealed TiNi films of $0.4 \mu \mathrm{m}$ thickness were used to analyse the composition depth profile of TiNi-SiN-Si interfaces by Auger electron spectroscopy (AES), using a Perkins-Elmer 600 model with $\mathrm{Ta}_{2} \mathrm{O}_{5}$ as the reference for depth estimation. The ion-bombardment rate of AES is about $25 \AA \mathrm{min}^{-1}$. The elemental profiles of $\mathrm{O}, \mathrm{N}, \mathrm{Ti}, \mathrm{Ni}$ and $\mathrm{Si}$ across the TiNi-SiN-Si interfaces were obtained. The annealed TiNi films of $1.5 \mu \mathrm{m}$ thickness were used to detect the phases and to observe the cross-sectional microstructures of interfaces. Cross-sectional transmission electron microscopy (TEM) specimens were fabricated by grinding, dimpling and ion milling at $5 \mathrm{kV}$ to perforation. The sector speed control whisperlock of the Gatan Duomill at 
liquid- $\mathrm{N}_{2}$ temperature was used to minimize the effects of different ion-milling rates of $\mathrm{TiNi}, \mathrm{SiN}$ and $\mathrm{Si}$ in cross-sectional TEM specimens. Microstructural observation was performed using a $4000 \mathrm{FX}$ (JEOL) transmission electron microscopy operated at $400 \mathrm{kV}$ with $2.6 \AA$ point-to-point resolution. The camera constant was $41 \AA \mathrm{mm}$. X-ray diffraction (XRD) tests were carried out on a Philips PW1710 X-ray diffractometer using $\mathrm{Cu} \mathrm{K} \alpha$ radiation. The power was $40 \mathrm{kV} \times 30 \mathrm{~mA}$ and the $2 \theta$ scanning rate was $0.008^{\circ} \mathrm{s}^{-1}$. The range of scanning angles was from $20^{\circ}$ to $90^{\circ}$. All XRD tests were taken from the top of sputtered specimens and normal to the TiNi-SiN-Si interfaces.

\section{§3. RESULTS AND DISCUSSION}

\subsection{As-deposited specimens and specimens annealed at $400^{\circ} \mathrm{C}$ for $30 \mathrm{~min}$}

Figure 1(a) shows the cross-sectional TEM image of an as-deposited $\mathrm{TiNi}$ / $\mathrm{SiN} / \mathrm{Si}$ specimen, and figure $1(\mathrm{~b})$ is the XRD result of the specimen annealed at $400^{\circ} \mathrm{C}$ for $30 \mathrm{~min}$. Figures 1 (a) and (b) indicate that the as-deposited TiNi films are amorphous, and that these films are stable even after annealing at $400^{\circ} \mathrm{C}$ for $30 \mathrm{~min}$. Figure 1 (c) shows the AES results for the as-deposited specimen. From figures 1 (a) and (c), it can be seen that the interface between the Si substrate and the SiN layer is quite sharp, but the interface between the SiN layer and the TiNi film is not clear and has a relatively higher $\mathrm{O}$ concentration. The reason for the latter may be that the specimens have a long holding time in the air in between different deposition procedures. In figure 1 (a), one can observe a layer of about $10 \mathrm{~nm}$ thickness with varying contrast in the $\mathrm{Si}$ substrate neighbouring the $\mathrm{SiN}-\mathrm{Si}$ interface. This layer can still be observed even after annealing at $700^{\circ} \mathrm{C}$ for $30 \mathrm{~min}$, and it is speculated that high-density defects induced by high-energy particle bombardment during the SiN PECVD occur. In figure 1 , there is no $\mathrm{Ni}$ atom diffusion crossing the TiNi-SiN-Si interfaces, although that has been observed in the TiNi-Si interface annealed at $400^{\circ} \mathrm{C}$ for $30 \mathrm{~min}$ (Wu et al. 2001).

\subsection{Specimens annealed at $500^{\circ} \mathrm{C}$ for $30 \mathrm{~min}$}

Figures 2 (a), (b) and (c) show the cross-sectional TEM image, the XRD results and the AES results respectively of a $\mathrm{TiNi} / \mathrm{SiN} / \mathrm{Si}$ specimen annealed at $500^{\circ} \mathrm{C}$ for $30 \mathrm{~min}$. From figure 2 (b), it can be seen that the TiNi film now has clearly crystallized to be a mixture of the B2 parent phase and B19' martensite. Its crystallization behaviour is similar to that of previous reports (Stemmer et al. 1997, Chen and Wu 1999, Wu et al. 2001). From figures 2 (a) and (c), the interface between the SiN layer and the Si substrate is still sharp, but that between the SiN layer and the TiNi film now forms a reaction layer with a thickness of about $10 \mathrm{~nm}$ on the TiNi side. This extra layer contains many $\mathrm{N}$ atoms, compared with figure 1 (c), indicating that $\mathrm{N}$ atoms have diffused from the $\mathrm{SiN}$ layer to react with the TiNi film at $500^{\circ} \mathrm{C}$. From figure 2 (b), this reaction layer is expected to be a $\mathrm{TiN}_{1-x}$ phase because the important XRD peaks of the $\mathrm{TiN}_{1-x}$ phase can be identified (Joint Committee for Powder Diffraction Standards 1995b). The sharp SiN-Si interface means that there is no clear atom diffusion crossing over this interface, even after annealing at $500^{\circ} \mathrm{C}$ for $30 \mathrm{~min}$.

\subsection{Specimens annealed at $600^{\circ} \mathrm{C}$ for $30 \mathrm{~min}$}

Figures 3 (a), (b) and (c) show the cross-sectional TEM image, the XRD results and the AES results respectively of a $\mathrm{TiNi} / \mathrm{SiN} / \mathrm{Si}$ specimen annealed at $600^{\circ} \mathrm{C}$ for $30 \mathrm{~min}$. Figure $3(\mathrm{~d})$ is the selected-area diffraction pattern of the area covering 

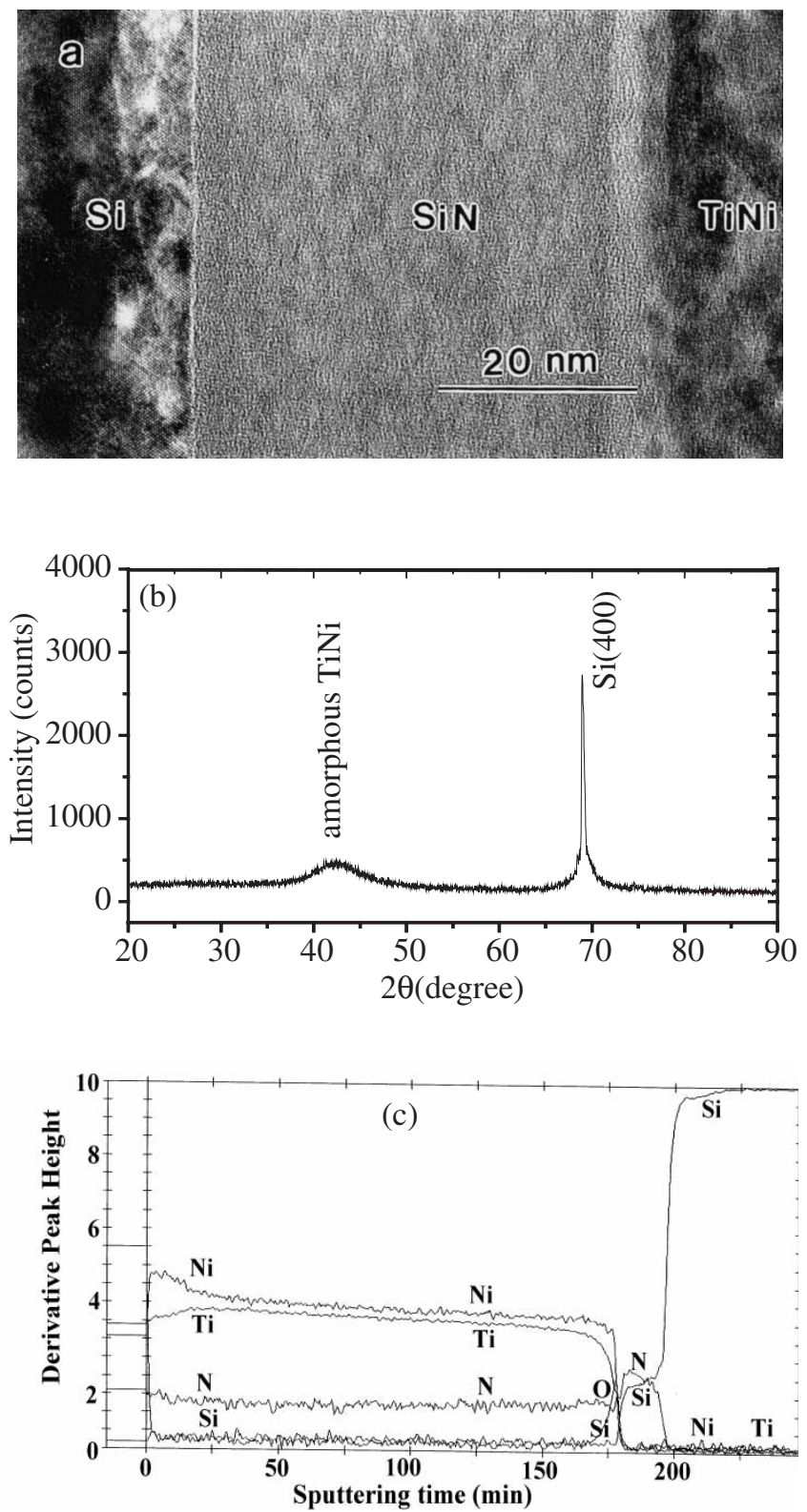

Figure 1. (a) The cross-sectional TEM image of the as-deposited $\mathrm{TiNi} / \mathrm{SiN} / \mathrm{Si}$ specimen, (b) the XRD results of the $\mathrm{TiNi} / \mathrm{SiN} / \mathrm{Si}$ specimen annealed at $400^{\circ} \mathrm{C}$ for $30 \mathrm{~min}$ and (c) the AES results of the as-deposited $\mathrm{TiNi} / \mathrm{SiN} / \mathrm{Si}$ specimen.

the $\mathrm{Si}-\mathrm{SiN}-\mathrm{TiNi}$ interfaces in figure 3 (a). There are spot and ring patterns superimposed in figure $3(\mathrm{~d})$. The spot pattern is identified as the $[011]_{\mathrm{Si}}$ zone axis, but the ring pattern has ring radii of about $4.15-4.63 \mathrm{~nm}^{-1}$. The ring of about $4.15 \mathrm{~nm}^{-1}$ radius is proposed to come from the $\{111\}$ plane of the $\mathrm{TiN}_{1-x}$ phase with $d=0.2447 \mathrm{~nm}$ (Villars and Calvert 1985) and/or the (002)-(020) plane of $\mathrm{Ti}_{2} \mathrm{Ni}_{3} \mathrm{Si}$ with $d=0.24 \mathrm{~nm}$ (Bardos et al. 1961). The ring of about $4.63 \mathrm{~nm}^{-1}$ radius consists of the spots that come from the $\{011\}_{\mathrm{B} 2}$ plane of the TiNi parent phase with the lattice 

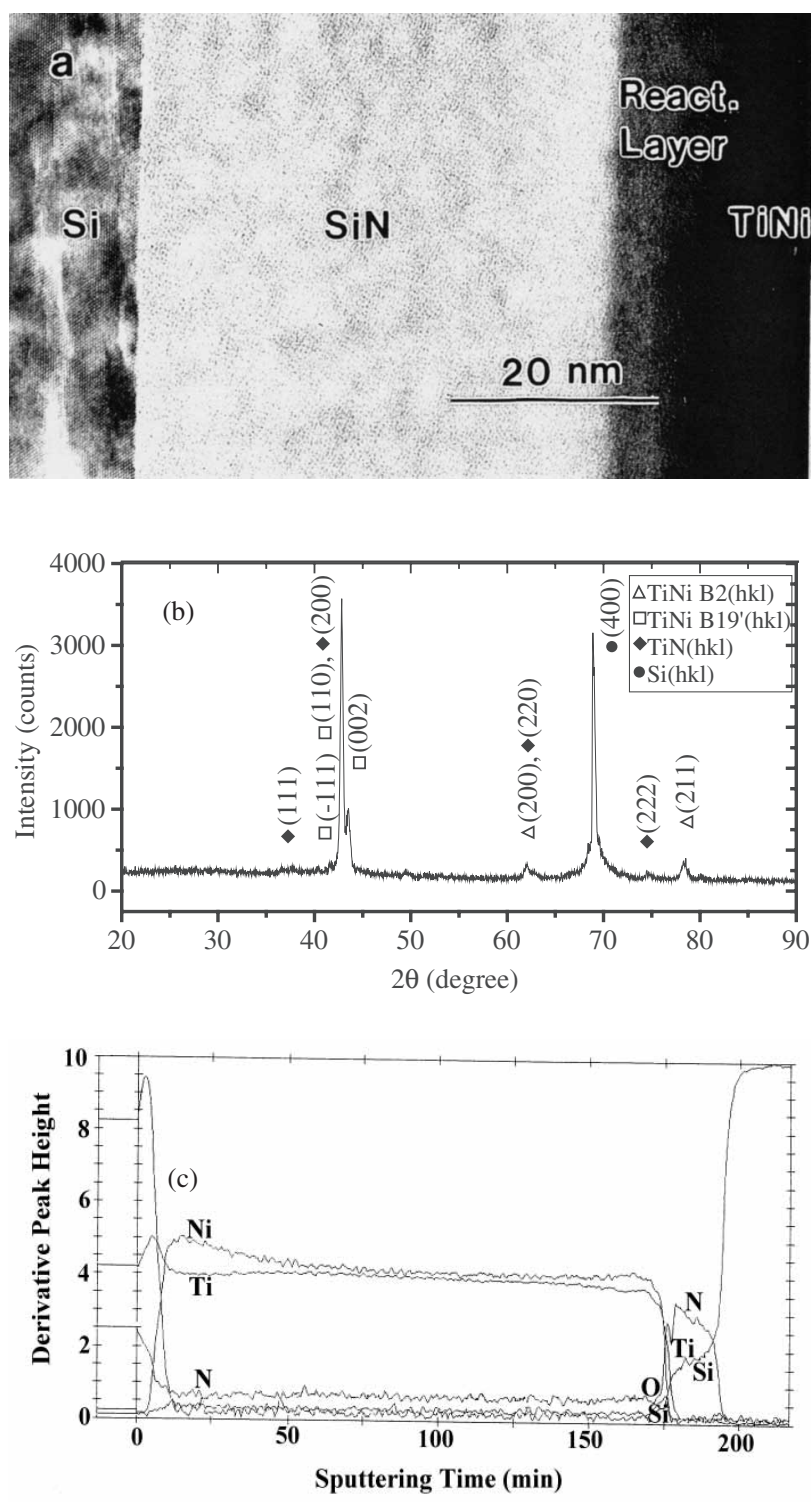

Figure 2. (a) The cross-sectional TEM image, (b) the XRD results and (c) the AES results of the $\mathrm{TiNi} / \mathrm{SiN} / \mathrm{Si}$ specimen annealed at $500^{\circ} \mathrm{C}$ for $30 \mathrm{~min}$.

constant $0.3015 \mathrm{~nm}$ and $d_{011}=0.213 \mathrm{~nm}$ (Philip and Beck 1957). From figure 3, the sharp interface between the SiN layer and the Si substrate is still observable, but the reaction layer between the $\mathrm{SiN}$ layer and the TiNi film is thicker (about $60 \mathrm{~nm}$ ) than that observed in specimen annealed at $500^{\circ} \mathrm{C}$ for $30 \mathrm{~min}$. The results in figures 3 (b), (c) and (d) indicate that the reaction layer contains a sublayer of $\mathrm{TiN}_{1-x}$ on the near-SiN side and a sublayer of the mixture of $\mathrm{Ti}_{2} \mathrm{Ni}_{3} \mathrm{Si}$ and $\mathrm{Ti}_{4} \mathrm{Ni}_{2} \mathrm{O}$ on the nearTiNi film. It is well known that the $\mathrm{Ti}_{2} \mathrm{Ni}$ phase can absorb much more $\mathrm{O}$ than $\mathrm{TiNi}$ can to form $\mathrm{Ti}_{4} \mathrm{Ni}_{2} \mathrm{O}$ (Honma 1987), and the cubic structures of $\mathrm{Ti}_{2} \mathrm{Ni}$ and $\mathrm{Ti}_{4} \mathrm{Ni}_{2} \mathrm{O}$ are similar, having almost the same lattice constant (Joint Committee for Powder Diffraction Standards 1995a,c). As seen from figure 2 (c), the high concentration 

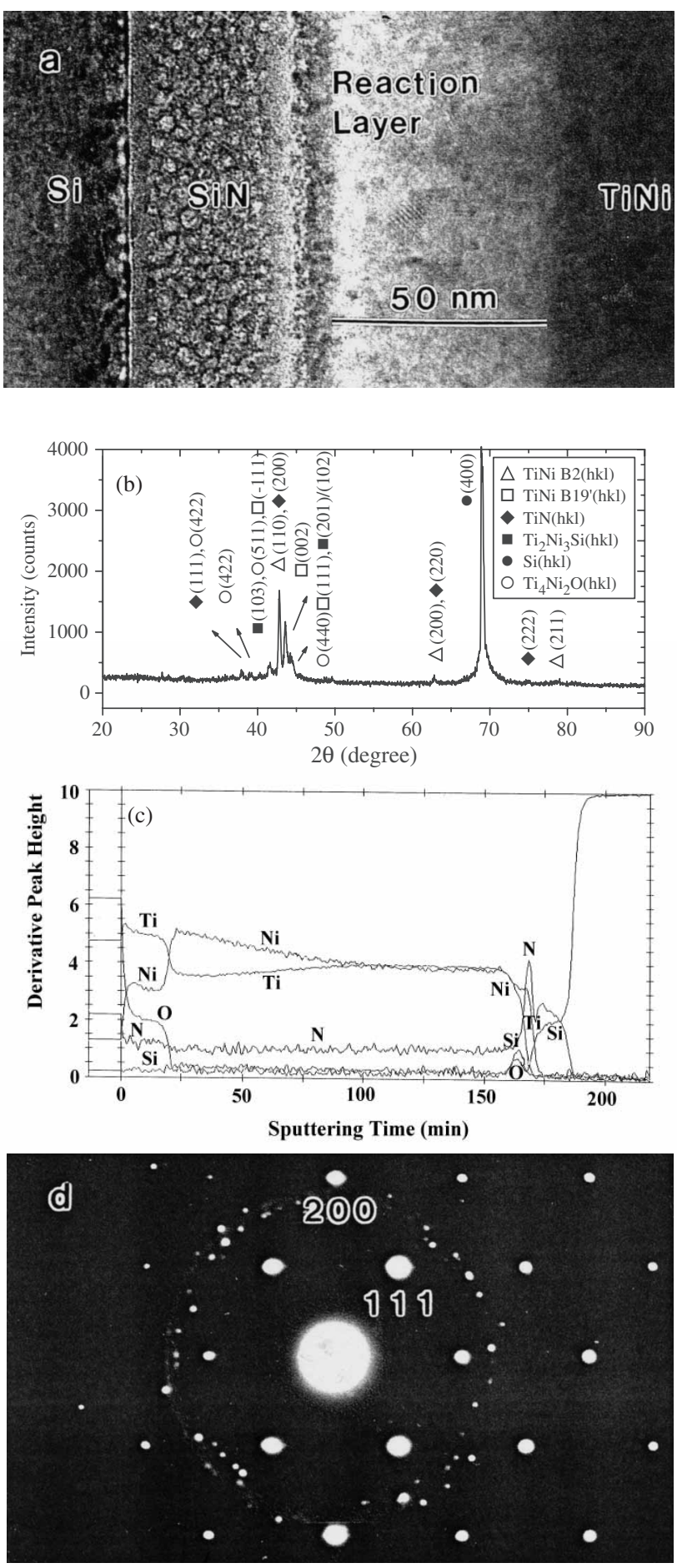

Figure 3. (a) The cross-sectional TEM image, (b) the XRD results, (c) the AES results and (d) the selected-area diffraction pattern of (a) of the $\mathrm{TiNi} / \mathrm{SiN} / \mathrm{Si}$ specimen annealed at $600^{\circ} \mathrm{C}$ for $30 \mathrm{~min}$. 
of $\mathrm{O}$ in this sublayer suggests the possibility of formation of $\mathrm{Ti}_{4} \mathrm{Ni}_{2} \mathrm{O}$. It is also suggested that $\mathrm{Ti}_{2} \mathrm{Ni}_{3} \mathrm{Si}$ forms in the reaction sublayer of figure 3 (a) because $\mathrm{Ti}_{2} \mathrm{Ni}_{3} \mathrm{Si}$ has been observed at the $\mathrm{TiNi}-\mathrm{Si}$ interface of the specimen annealed at about $525^{\circ} \mathrm{C}$ for $30 \mathrm{~min}$, when $\mathrm{Si}$ atoms have diffused across the interface (Stemmer et al. 1997). At the same time, the formation of $\mathrm{TiN}_{1-x}$ and $\mathrm{Ti}_{4} \mathrm{Ni}_{2} \mathrm{O}$ will cause deficit $\mathrm{Ti}$ atoms in TiNi film. This feature will favour the formation of the $\mathrm{Ti}_{2} \mathrm{Ni}_{3} \mathrm{Si}$ phase. Figure 3 also clearly indicates that $\mathrm{Si}$ atoms have migrated from the SiN layer to react with $\mathrm{TiNi}$ film at $600^{\circ} \mathrm{C}$ on the $\mathrm{TiNi} / \mathrm{SiN} / \mathrm{Si}$ specimen.

\subsection{Specimens annealed at $700^{\circ} \mathrm{C}$ for $30 \mathrm{~min}$}

Figures 4 (a), (b) and (c) show the cross-sectional TEM image, the XRD results and the AES results respectively of a $\mathrm{TiNi} / \mathrm{SiN} / \mathrm{Si}$ specimen annealed at $700^{\circ} \mathrm{C}$
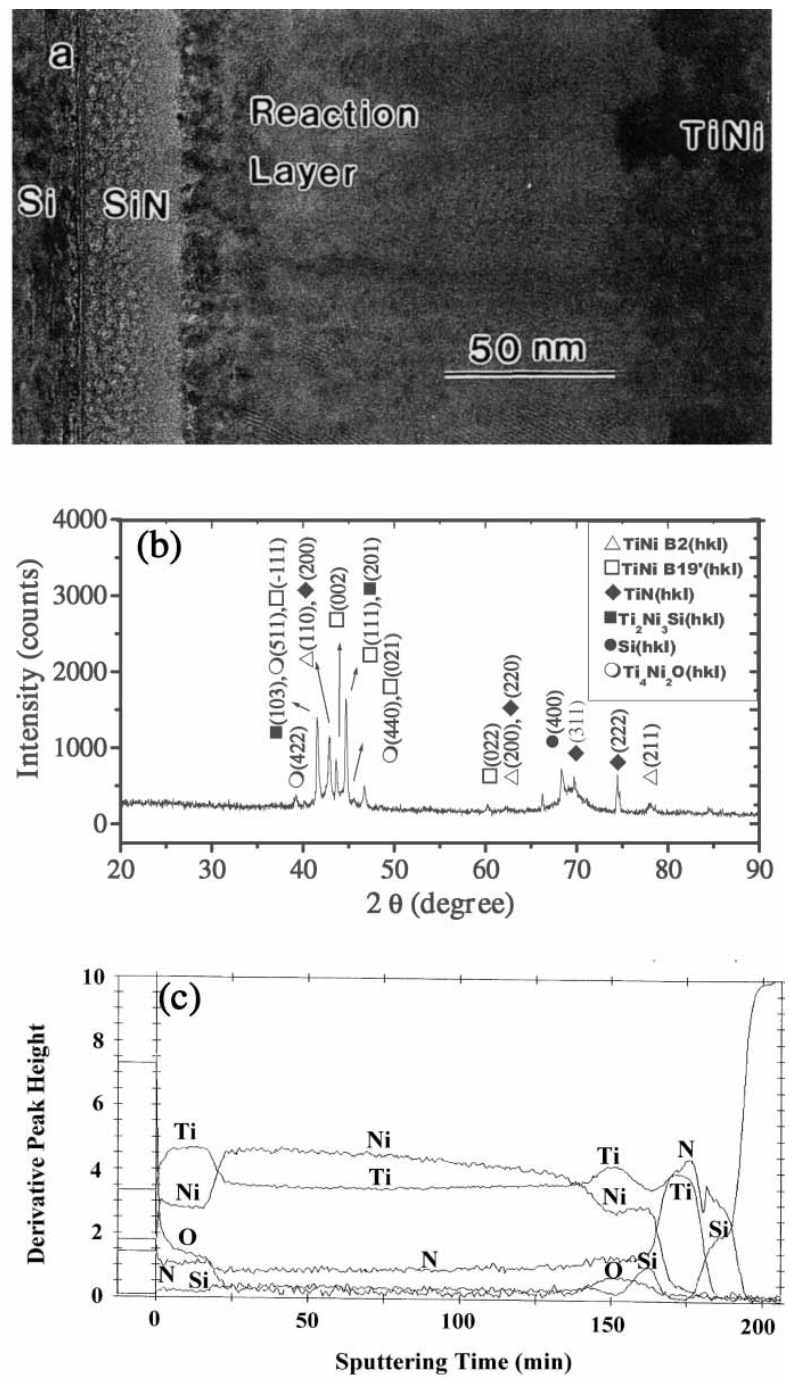

Figure 4. (a) The cross-sectional TEM image, (b) the XRD results and (c) the AES results of the $\mathrm{TiNi} / \mathrm{SiN} / \mathrm{Si}$ specimen annealed at $700^{\circ} \mathrm{C}$ for $30 \mathrm{~min}$. 
for $30 \mathrm{~min}$. In figures 4 (a) and (c), the SiN-Si interface is still sharp, the SiN-TiNi interface has a reaction layer with a thickness of about $150 \mathrm{~nm}$. In figures 4 (b) and (c), the reaction layer of $\mathrm{SiN}-\mathrm{TiNi}$ contains the sublayers of $\mathrm{TiN}_{1-x}, \mathrm{Ti}_{2} \mathrm{Ni}_{3} \mathrm{Si}$ and $\mathrm{Ti}_{4} \mathrm{Ni}_{2} \mathrm{O}$, which are the same as those observed in figure 3 except that now $\mathrm{Ti}_{2} \mathrm{Ni}_{3} \mathrm{Si}$ and $\mathrm{Ti}_{4} \mathrm{Ni}_{2} \mathrm{O}$ have separated into two sublayers. Figure 4 (c) suggests that these sublayers have the sequence $\mathrm{TiNi} / \mathrm{Ti}_{4} \mathrm{Ni}_{2} \mathrm{O} / \mathrm{Ti}_{2} \mathrm{Ni}_{3} \mathrm{Si} / \mathrm{TiN}_{1-x} / \mathrm{SiN}$. However, figure 4 (a) shows that there are no clear interfaces between these sublayers. This feature indicates that these reaction compounds are mixed at the interfaces of the sublayers. In figure $4(\mathrm{~b})$, no sharp $(400)_{\mathrm{Si}}$ peak can be observed. This may be due to the formation of a thick reaction layer at the TiNi-SiN interface after annealing at $700^{\circ} \mathrm{C}$ for $30 \mathrm{~min}$. From figure $4(\mathrm{~b})$, some minor XRD peaks still cannot be identified, a feature that merits further study.

\subsection{Effect of SiN diffusion barrier on the interfacial reactions of $\mathrm{TiNi} / \mathrm{SiN} / \mathrm{Si}$ specimens}

The thicknesses of $\mathrm{SiN}$ and reaction layers shown in figures 1-4 are measured. Figure 5 shows the curves of the thickness of $\mathrm{SiN}$ layer and that of reaction layer of $\mathrm{SiN} / \mathrm{TiNi}$ versus the annealing temperature in $\mathrm{TiNi} / \mathrm{SiN} / \mathrm{Si}$ specimens annealed at $400-700^{\circ} \mathrm{C}$ for $30 \mathrm{~min}$. For comparison, the curve of the thickness of reaction layer versus the annealing temperature in $\mathrm{TiNi} / \mathrm{Si}$ specimens annealed in the same conditions is also plotted in figure 5 (Wu et al. 2001). From figure 5, the significant effect of the $\mathrm{SiN}$ layer as a diffusion barrier in $\mathrm{TiNi} / \mathrm{SiN} / \mathrm{Si}$ can be recognized. In the case of $\mathrm{TiNi} / \mathrm{Si}$ without the diffusion barrier, $\mathrm{Ni}$ atoms can diffuse to form $\mathrm{NiSi}_{2}$ after annealing at $400^{\circ} \mathrm{C}$ for $30 \mathrm{~min}$, and they are the primary diffusion species for annealing temperatures below $600^{\circ} \mathrm{C}(\mathrm{Wu}$ et al. 2001). However, in the case of $\mathrm{TiNi} / \mathrm{SiN} / \mathrm{Si}$ with $\mathrm{SiN}$ as a diffusion barrier, $\mathrm{N}$ and $\mathrm{Si}$ atoms diffuse from the $\mathrm{SiN}$ layer into the TiNi film at $500^{\circ} \mathrm{C}$ and $600^{\circ} \mathrm{C}$ respectively. Clearly, the Ni atoms are not the primary diffusion species in annealed $\mathrm{TiNi} / \mathrm{SiN} / \mathrm{Si}$ specimens owing to the existence of the $\mathrm{SiN}$ thermal barrier. This feature also causes the sharp SiN-Si interface in TiNi/SiN/ Si specimens, even after annealing at $700^{\circ} \mathrm{C}$ for $30 \mathrm{~min}$.

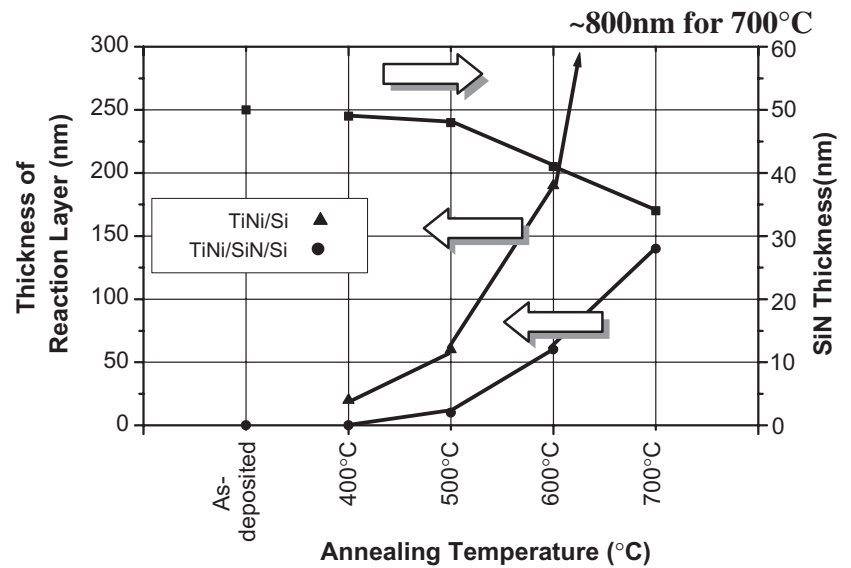

Figure 5. The curves of the thicknesses of the total reaction layer versus the annealing temperature for $\mathrm{TiNi} / \mathrm{SiN} / \mathrm{Si}$ and $\mathrm{TiNi} / \mathrm{Si}$ specimens annealed at $400-700^{\circ} \mathrm{C}$ for $30 \mathrm{~min}$. The curve of the thickness of SiN layer versus the annealing temperature for $\mathrm{TiNi} / \mathrm{SiN} / \mathrm{Si}$ specimens is also plotted. 
The interfacial microstructures of $\mathrm{TiNi} / \mathrm{SiN} / \mathrm{Si}$ specimens annealed at $400-700^{\circ} \mathrm{C}$ for $30 \mathrm{~min}$ are also different from those of $\mathrm{TiNi} / \mathrm{Si}$ specimens annealed under the same conditions. This characteristic can be understood from the fact that the diffusion species have changed at $\mathrm{TiNi} / \mathrm{SiN} / \mathrm{Si}$ and $\mathrm{TiNi} / \mathrm{Si}$ interfaces. In this study, the specimen annealed at $700^{\circ} \mathrm{C}$ for $30 \mathrm{~min}$ has reaction sublayers of $\mathrm{TiN}_{1-x}, \mathrm{Ti}_{2} \mathrm{Ni}_{3} \mathrm{Si}$ and $\mathrm{Ti}_{4} \mathrm{Ni}_{2} \mathrm{O}$ at the TiNi-SiN interface. Of these, $\mathrm{TiN}_{1-x}, \mathrm{Ti}_{2} \mathrm{Ni}_{3} \mathrm{Si}$ and $\mathrm{Ti}_{4} \mathrm{Ni}_{2} \mathrm{O}$ have been found in specimen annealed at $600^{\circ} \mathrm{C}$ for $30 \mathrm{~min}$ and $\mathrm{TiN}_{1-x}$ is formed at much lower annealing temperatures, for example in the specimen annealed at $500^{\circ} \mathrm{C}$ for $30 \mathrm{~min}$. This feature indicates that the formation of these phases is closely related to their free energies of formation, and is also dependent on the primary diffusion species crossing the interfaces. For example, according to the $\mathrm{Ti}-\mathrm{Si}-\mathrm{N}$ and $\mathrm{Ni}-\mathrm{Si}-\mathrm{N}$ ternary systems (Rogl and Schuster 1992), $\mathrm{TiN}_{1-x}$ has a lower free energy to form compared with $\mathrm{NiSi}, \mathrm{NiSi}_{2}, \mathrm{Ti}_{5} \mathrm{Si}_{3}$ and $\mathrm{Si}_{3} \mathrm{~N}_{4}$. At the same time, at $500^{\circ} \mathrm{C}, \mathrm{N}$ atoms are the primary diffusion species at the TiNi-SiN interface; therefore $\mathrm{TiN}_{1-x}$ can be formed at a lower temperature than other compounds in this study.

\section{$\S 4$. CONCLUSION}

$\mathrm{SiN}$ with a thickness of $50 \mathrm{~nm}$ on $\mathrm{Si}(100)$ as a thermal barrier was obtained by PECVD. TiNi films were rf sputtered on a $\mathrm{SiN} / \mathrm{Si}$ substrate and then annealed at $400-700^{\circ} \mathrm{C}$ for $30 \mathrm{~min}$; and their interfaces are studied using TEM, AES and XRD analyses. Experimental results show that the thickness of reaction layer in $\mathrm{TiNi} /$ $\mathrm{SiN} / \mathrm{Si}$ specimens is clearly reduced, compared with that in $\mathrm{TiNi} / \mathrm{Si}$ specimens under the same annealing conditions. The significant effect of the $\mathrm{SiN}$ layer as a diffusion barrier in $\mathrm{TiNi} / \mathrm{SiN} / \mathrm{Si}$ can be recognized. In this study, $\mathrm{N}$ and $\mathrm{Si}$ atoms diffuse from the $\mathrm{SiN}$ layer on to the TiNi film at $500^{\circ} \mathrm{C}$ and $600^{\circ} \mathrm{C}$ respectively. This feature allows the $\mathrm{TiN}_{1-x}$ phase and mixed $\mathrm{TiN}_{1-x}$ and $\mathrm{Ti}_{2} \mathrm{Ni}_{3} \mathrm{Si}_{-}-\mathrm{Ti}_{4} \mathrm{Ni}_{2} \mathrm{O}$ phases to be formed at $500^{\circ} \mathrm{C}$ and $600^{\circ} \mathrm{C}$ respectively. After annealing at $700^{\circ} \mathrm{C}$ for $30 \mathrm{~min}$, the reaction layer has sublayers in the sequence $\mathrm{TiNi} / \mathrm{Ti}_{4} \mathrm{Ni}{ }_{2} \mathrm{O} / \mathrm{Ti}_{2} \mathrm{Ni}_{3} \mathrm{Si} / \mathrm{TiN}_{1-x} / \mathrm{SiN} / \mathrm{Si}$. The formation of $\mathrm{TiN}_{1-x}, \mathrm{Ti}_{2} \mathrm{Ni}_{3} \mathrm{Si}$ and $\mathrm{Ti}_{4} \mathrm{Ni}_{2} \mathrm{O}$ phases is suggested to be related to their free energies of formation and to be dependent on the primary diffusion species crossing the interfaces. These results also demonstrate that the diffusion species observed in TiNi-SiN-Si specimens are quite different from those observed in $\mathrm{TiNi} / \mathrm{Si}$ specimens.

\section{ACKNOWLEDGEMENT}

The authors are grateful for the financial support of this research from the National Science Council, Taiwan, under grant NSC 88-2216-E002-013.

\section{REFERENCES}

Bardos, D. I., Gupta, K. P., Gupta, K. P., and Beck, P. A., 1961, Trans. metall. Soc. AIME, 221, 1087.

Bendahan, M., Seguin, J., Canet, P., and Carchano, H., 1996, Thin Solid Films, 283, 61. Chang, M., Wong, J., and Wang, D. N. K., 1988, Solid St. Technol., 31, 193.

Chen, J. Z., and Wu, S. K., 1999, Thin Solid Films, 339, 194.

Honma, T., 1987, Shape Memory Alloys, edited by H. Funakubo, translated by J. B. Kennedy (New York: Gordon and Breach), p. 99.

Joint Committee for Powder Diffraction Standards, 1995a, Powder Diffraction File, Version 2.16 (Swarthmore, Pennsylvania: International Center for Powder Diffraction Data), card 05-0694; 1995b, ibid., card 06-0642; 1995c, ibid., card 18-0898.

Mar, K. M., and Samuelson, G. M., 1980, Solid St. Technol., 23, 137. 
Matsunaga, T., Kajiwara, S., Ogawa, K., Kikuchi, T., and Miyazaki, S., 2000, Mater. Sci. Forum, 327-328, 175.

Miyazaki, S., and Ishida, A., 1999, Mater. Sci. Engng, A273-A275, 106.

Philip, T. V., and Beck, P. A., 1957, Trans. metall. Soc. AIME, 209, 1269.

Rogl, P., and Schuster, J. C., 1992, Phase Diagrams of Ternary Boron Nitride and Silicon Nitride Systems (Metals Park, Ohio: American Society for Metals), pp. 175, 198.

Sмith, D. L., 1995, Thin-Film Deposition_Principles and Practice (New York: McGraw-Hill), p. 545 .

Stemmer, S., Duscher, G., Scheu, C., Heuer, A. H., and Ruhle, M., 1997, J. Mater. Res., 12, 1734 .

Villars, P., and Calvert, L. D., 1985, Pearson's Handbook of Crystallographic Data for Intermetallic Phases, Vol. 3 (Metals Park, Ohio: American Society for Metals), p. 2794.

Wolf, R. H., and Heuer, A. H., 1995, J. Microelectromech. Systems., 4, 206.

Wu, S. K., Chen, J. Z., Wu, Y. J., Wang, J. Y., Yu, M. N., Chen, F. R., and Kai, J. J., 2001, Phil. Mag. A, 81, 1939. 